\title{
CONSERVATION OF BIODIVERSITY IN MANGROVE ECOSYSTEM IN SRI LANKA
}

\author{
Sunil Liyanage \\ Department of Wild Life Conservation
}

Mangrove ecosystem is one of the most threallened natural systems in Sri Lanka and total extent of mangrove in this country is about 12.500 ha according to recent studies. The hiodiversity assessments of mangrove hahilats in Sri Lamka have proved that though lhe extent of mallgrove is small, it has greater diversity compared to Asia-pacific region. However, lack of awareness and management as well as poor protection slallus have paved the way for destruction of this valuable natural system.

The sludies shows that there are ahout 30 mangrove species in Sri Lanka and these specics are distributed in many isolated habitats along the inter-tidal regions of coastal zone. A detail study was carried out to assess the mangrove biodiversity of Sri Lanka and the study area was confined to north western. western and southern coastal helt. The results show that the distribulion pattern and range and the population size of the cach species vary from one to another making conservation of tolal mangrove biodiversity of Sri Lanka a difficult task. Based on the population size and the distribution range, species could be divided to groups that give a better criterion in selection of mangrove habitats for comservation. Based on distribution range, species could be divided as widely distributed. restricted to ecological regions and restricted to few habilats and based on population size as common, less common and rare.

The analysis of dalla shows that more than 8 habitats are necessary to conserve tolal mangrove diversily. However. lew species are limiled to less than ten individuals even within their habitats making in situ conservation not fully guarantecing the total conservation of total diversity. In view of this, it is necessary to take immediate actions to comserve mangrove biodiversily of the country in a more scientific and systematic way to ensure the survival of these species. 